UDC $621.853: 620.172$

\title{
ワイヤロープに生ずる断線についての基礎的研究
}

(第 1 報 $)^{*}$

正会員芹苗陽 ${ }^{*}$

\section{A Fundamental Study on Breakage in the Wire-Rope (1st Report)}

\section{Yo SERITA}

Wire breaking occurred in the main rope of the aerial rope way, and some tests on wire breaking were tried, and results obtained are as follows.

1. Wire breaking appeared more quickly when hardness of one pulley was more higher than the others.

2. Wire breaking was retarded when sagging of main rope was small.

3. There were 2 sort of wire breaking viz., crack occurred first only in the upper side of wire and then breaking happened, and crack occurred both in the upper and lower sides of wire.

4. When material of pulley was made of soft metal, cracks occuring in the main rope wire were very few, so, breaking of wire was delayed and then increasing speed in the breakings of wire in a main rope was retarded.

5. Scanty strain was generated in the wire when soft roller was used, and when the hardness of roller was higher than that of the former larger strain was generated.

These results were obtained with pilot apparatus of aerial rope way 1st, 2nd and 4th nucha. 5 th cervix was obtained by wire testing machine which was designed by our college, and the 3rd cervix was obtained through these two testings.

\section{1. 緒言}

ワイヤロープに発生する断線についてはいろいろな角 度から考察されてきているようであるが，末だ断線発生 の原因について，はつきりしない点もあるようである。 特に索道の場合安全率を低くすると断線の発生を打そく するといら現場報告，あるいはこれをいくぶん理論ずけ て述べているものああるようであるが，現在架空索道の 場合鉱山保安規則で 4 と定められているよ5であり1， また第 5 回ワイヤロープ研究会講演集では安全率を 3 と するのが最適であると述べている2)。一般機械設備にお いては安全率が大きいほど安全であるので，一特現場で は安全率を4〜 位京で増したが断線を阻止するのに役 立たず，結局 2.7 ３.5 に落着く傾问にあるという報告も

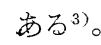

従来断線の実験には Haigh Robertson 疲労試験機安 用いたもの年 7)扛よびその他の試験機を作つて笑験を行 つたもの8),9)など多数あるが，筆者は数年来小形である が屋内架空索道装㯰交作つて滑車材質の変化がワイヤロ ープの摩耗に与える影響について契験を行なつているが

* 昭和 33 年11月21日受付

** 秋田大学教授 治金学教室 これまで荷重を500kg こして笑験を行つた際には，荷重 を50,000回往復しても軌索の断線は目立ななかつたが， 荷重丟 $1,000 \mathrm{~kg}$ に増加してからは滑車材料のいかんにか かわらず臣とんど断線を発生し，激しい時は荷重往復回 数 17,100 回て断線が多く発生して装置の継続運転不能と なるよらな事む市つた。このように断線が多く発生した ので断線に対する滑車材料の影響について考察し，これ に補足的に軌索張力を变化して断線発生状況もしらべ, また素線の断線試験についても新しく装置を作つて実験 を行なつたので，これらの結果について述べる。

\section{2. 実 験 装 置}

\section{$2 \cdot 1$ 索道装置}

実験装置は第 1 区に示したように，高さ $2 \mathrm{~m}$ の鉄塔を $7 \mathrm{~m}$ 間隔に建て, この鉄塔間に軌索として $6 \times 7$ 裸ラング $Z \exists リ 2$ 種 $26 \mathrm{~mm}$ を用い, 軌索を 2 本㲀つて同時に 2 種 類の実験を行なえるように作つてある。各軌罙には荷重 $1,000 \mathrm{~kg}$ 定釣り，荷重は軌菜上に2 個の滑車で支えられ る。荷重ならびに滑車の形状をそれぞれ第 2 図-1,2 に 示す。荷重は戞索によつて交走式に軌索上を走る。曳索 の運転は第1这右下に見える電動機により動かされる巻 上機によつて行な私るが，電動機の運軽は別に作つた 


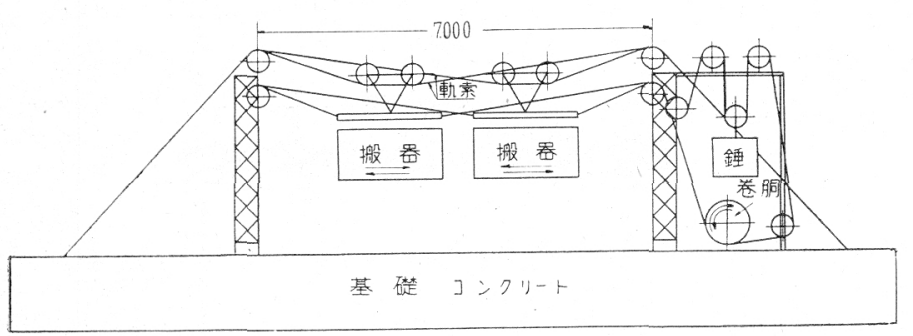

第 1 図索道実験装置略図
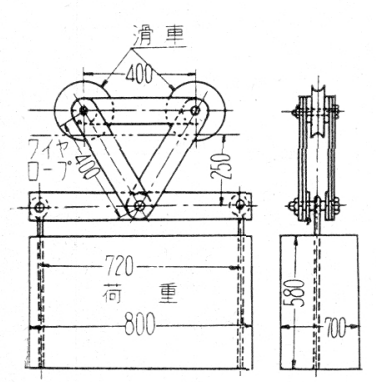

第 2 図-1 搬器

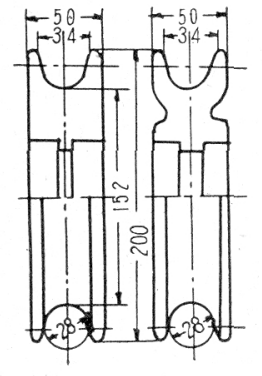

第 2 図 -2 搬器用滑車

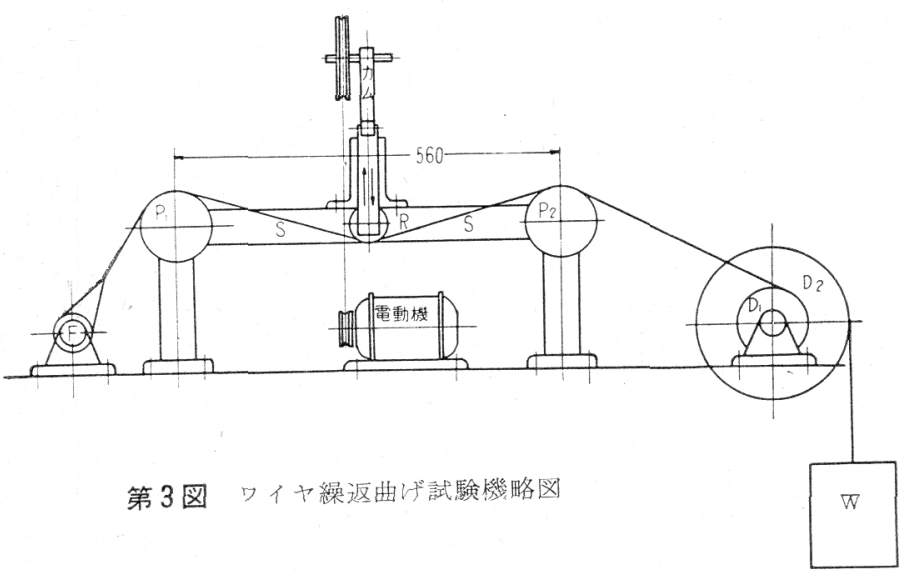

り付け， $\mathrm{D}_{2}$ に別に細いワイヤロープを巻さつけて一端

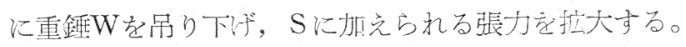

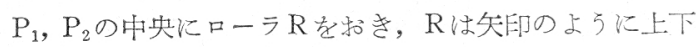
動する軸の下端に取り付けられている。い屯この軸を下 方に動かすこRはSを下方に押しつけるが，Rの下がる につれてRは僅かにS 上を転る。Rにはボールベヤリン グを用いている。束た同時に $\mathrm{P}_{2}, \mathrm{D}_{1}, \mathrm{D}_{2}$ も回転してW も上方に持ら上げられる。軸の上下速度が早いと $\mathrm{S}$ が $\mathrm{P}_{1}, \mathrm{P}_{2}$ を叮き，またWの自由落下沈よつて $\mathrm{S}$ に余分の 応力が加党られるので軸の上下動は每分24回の極めてお そい速度に調節してある。ローラ上下の回数は回転計に ようて自動的に示され，ワイヤが划断步 れば自動的に電源が切れて試験機の運転 は停止する。

\section{3. 実験試料および実験方法}

\section{$3 \cdot 1$ 索道断線実験}

軌索には2・1に述べたものを用いたが 滑車を新しい物と取り替觉る每に新しい ロープと張り替えて実験を行なつさが， ロープは 1 会社の1本の1巻のロープか ら必要長さずつ切り取つて用い, 笑験に 入るに先立つてロープに整布してあるコ ンポジションオイルそガソリンと刷毛と

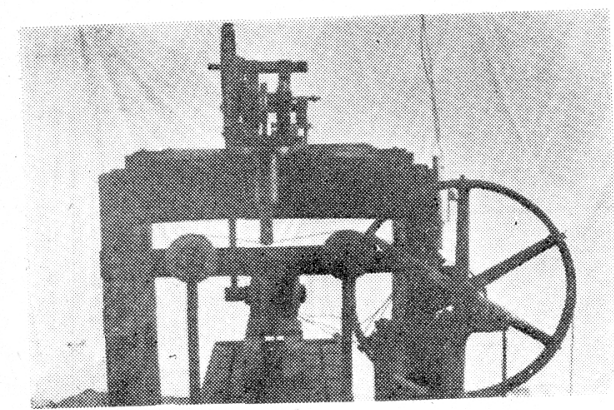

写真1ワイヤ繰返曲壮試験機

自動運転装置により行なわれ，電動機の運転時間間隔は 正転・休止・逆転・休止が $3,2,3,2$ 秒であり，これが荷 重の 1 往復である。荷重の動く距離は $3.8 \mathrm{~m}$ で荷重速度 は $61 \mathrm{~m} / \mathrm{min}$ となつている。荷重の軌索上学動く往復回

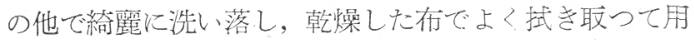
いた。ロープ張力は荷重をスパン中央に鈎り下げ，ロー

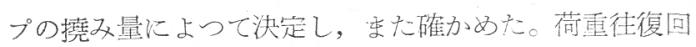
数はワイヤ断線が少ないるのは50,000回委て，柰た断線 の多いものはロープが急に伸び出すまで続けた。

荷重用滑車はいずれの村質でも同時に作つた第 2 図-2 に示す同形の滑車 2 個ずつを 1 つ荷重に取り付けて奏 験を行つた。用いた滑車材質は次の6 種類である。普通 鋳鉄，構造用炭素鋼第 9 種，自動古用バ亦鋼，僌鋼，硬

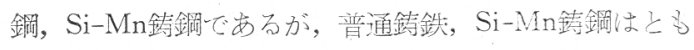
飞㜞荣撓又を変化して用いたので，それぞれ４回，2 回用い，また軟鋼，硬鋼，Si-Mn鋳鋼は熱処理により， 东た普通鋳鉄は急椧鉦造によりチルド鋳物として滑車硬 さを变化して用いたので, 滑車は合計13回取り替光26個、 
用いたのー京るが，鋳鉄の場合滑車の損耗激しく，滑車 を途中て新品と取り替光たので軦索は12本用いている。 勘菜撓子は588，400，296，221 mmの4 種類に変化した。 また実験終了後使用済の滑車を切断乙て材料の硬さを確 かめ，亲え斬案の破断片を切り取つて断線発生状況を確 加的。

\section{2 素線断線試験}

実験試料は2 1 項で述べた $26 \mathrm{~mm}$ 軌萦の素線と同径， 同質のフイヤを用いた。線径は $2.86 \mathrm{~mm}$ である。ローラ としてボールベヤリングNo. 6303*を用いた。京たワイ ヤヒズミ測定用ローラは第1 表の滑車番号 No. 16, 25, 17 の使用済滑車から幅泛in, 外径1 I / inのローラを削り 出し, こ礼う3 種頪のローラを交互に取り替党, 写真 1 に示した装置によってワイヤ下面に引き起されるヒズミ を測定しキが，その際はワイヤを真直になる程度に軽く 帪つてかいて抵抗線ヒズミ計を張り付け，ローラが最下 估に下のた時にワイヤに接触する点のワイヤの下の点を 中心にしてヒズミ計を张り付けた。ヒズミ計は共和無線 研究所のSK-47茫定用いた。その際のワイヤのスパンは $560 \mathrm{~mm}$, ローラ・ストロークは $24 \mathrm{~mm}$ ，ワイヤに加光 不張力は300kgとした。

まン本実験て得た断線の破片を切り取つてワイヤ内部

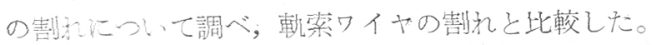

\section{4. 実 験 結 果}

\section{$4 \cdot 1$ 素道実験}

$4 \cdot 1 \cdot 1$ 索道断線実験 枵索の断線状態它写真 2 に 示乙た。断線実験の結果它第1表に示すす。表《は㰻菜の 撓及上滑車の侕さ技よび滑車の熱処理要領その他につい

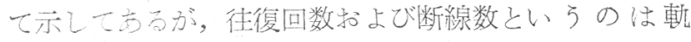

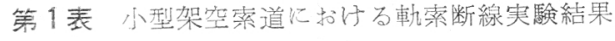

\begin{tabular}{|c|c|c|c|c|c|c|c|}
\hline 滑車 & 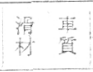 & 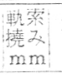 & $\begin{array}{l}\text { 荷重 } \\
\mathrm{kg}\end{array}$ & 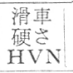 & 往复粮 & 断線 & 滑車の条件 \\
\hline $\begin{array}{l}24 \\
16 \\
19\end{array}$ & 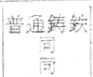 & $\begin{array}{l}588 \\
400 \\
296\end{array}$ & $\begin{array}{l}1,000 \\
1,000 \\
1,000\end{array}$ & $\begin{array}{l}231 \\
185 \\
174\end{array}$ & $\begin{array}{l}25,350 \\
50,000 \\
22,280\end{array}$ & $\begin{array}{r}58 \\
6 \\
0\end{array}$ & $\begin{array}{l}\text { 熱処理なし } \\
\text { ”/ } \\
\text { ” }\end{array}$ \\
\hline 22 & 可 & 296 & 1,000 & $247^{2}$ & 22,280 & & "No. 19 祃事渎用後 \\
\hline 18 & 同二 & 296 & 1,000 & 473 & 25,800 & 99 & 急冷鋳造 \\
\hline 20 & 宸来蜩 & 296 & 1,000 & 289 & 20,650 & & 宸素鋼第 9 種 ${ }^{\circ} 0^{\circ} \mathrm{C}$ 油冷 \\
\hline 17 & 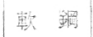 & 296 & 1,000 & $<150$ & 31,500 & 59 & $\begin{array}{l}\text { 鍛造後 } 800 \\
\text { (HRB } 68)\end{array}$ \\
\hline $\begin{array}{l}26 \\
21\end{array}$ & 硬司銅 & $\frac{296}{296}$ & $\begin{array}{l}1,000 \\
1,000\end{array}$ & $\begin{array}{l}240 \\
178\end{array}$ & $\begin{array}{l}31,090 \\
21,150\end{array}$ & $\begin{array}{r}75 \\
64\end{array}$ & $\begin{array}{l}950^{\circ} \mathrm{C} \text { 水冷 } \\
300^{\circ} \mathrm{C} 1 \text { 洔間燎鈎 }\end{array}$ \\
\hline 23 & & 296 & 1,000 & 351 & 17,100 & 76 & 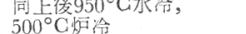 \\
\hline 25 & $\mathrm{Si}-\mathrm{Mn}$ & 296 & 1,000 & 192 & 25,500 & 57 & $800^{\circ} \mathrm{C} 1$ 時問焼鈍 \\
\hline 27 & 同 & 296 & 1,000 & 313 & 20,000 & 66 & $\begin{array}{l}\text { 同上偻 } 950^{\circ} \mathrm{C} \\
500^{\circ} \mathrm{C} \text { 泠 }\end{array}$ \\
\hline 28 & 可 & 221 & 1,000 & - & 3 & & $800^{\circ} \mathrm{C} 1$ 時間烠 \\
\hline 15 & 発条鎇 & 400 & 1,000 & 256 & 22,700 & 89 & 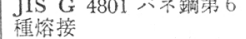 \\
\hline
\end{tabular}

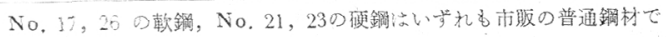
के

* 峃列固定形中荷重型ラジアル玉棔受

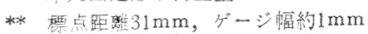

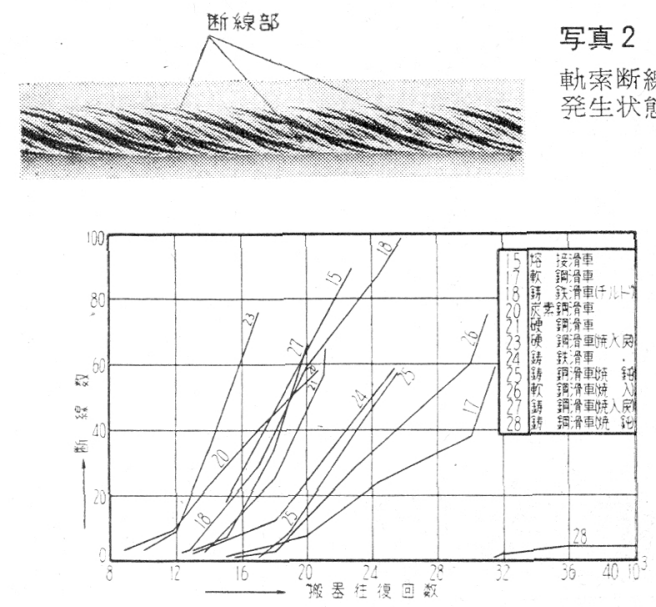

第4図ワイヤ断線数の增加状態図

荣に断線它多く発生し，それ以後の実駼継続が危険と諗 め中止した際の往復回数であり，先の時の断線数であ

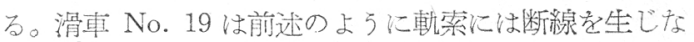
からたが，滑車が摩耗して 2 つに割れたので No. 22 と 取り替光て実験を継繶したものである。炘線発生数の増 加傾向荷重往復回数と比較して示寸と第 4 図の上万て ある。

こ机らの結果を見て分ることはNo. 24，16，19，22の 滑車は同一材質の滑車であり（普通鋳鉄）いずれも硬さ は異なるが，主索撓及の多い程断線の発生も早〉，乙た からて軌索が危険て使用に柎觉な?なるまでの荷重往復 回数毛少なく断線数も多い。No. 25，28(どちらも SiMn 鋳銅滑車) についても同様の事が、える。すなう 撓及が少ないことはもちろれ軌索張力が大であるこにて ありここ礼が断缐の発生を少なくしている。また No.

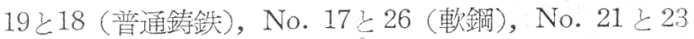

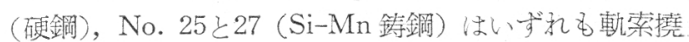
又は同一であり滑車材質は同じであるが，滑車製作条件 が黑なり熱処理式は急冷鋳造によつて滑車の硬さを変化 しているが，滑車硬さをあげるといずれの場合でも往復 回数が少なくなり，軌索の寿命浪短かい。

$4 \cdot 1 \cdot 2$ 軌索断線部および滑車材料について 㜞索 の断線はいずれも軌荣上面の山切れで，断線数が多くな る.と断線した部分の下に重なつている線にも断線を生ず るようになるが，この断線部を起して金鋸で切り取つて これを試料とし，ワイヤを繸に或いは横に輪切りに切断 し，研磨して顕微鏡で内部の割れについてしらべて見 た。先の結果第 4 図で線の比較的立つているるの, すな ネ゙, No. 23，27，15，18の滑車安用いたよ5な試料て は,ワイヤの破断した近くにワイヤ上面(軌荣として用い た時に滑車と接触した部分）から沢山の割れが出ており (第5 図-1参照)，杰たNo. 16，22，28の上万な滑車を用 


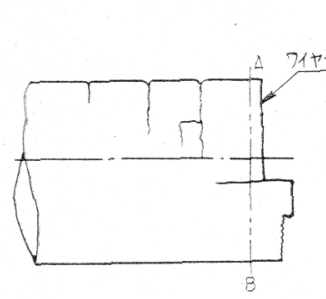

-1ワイヤ縦盺面 (C-D)

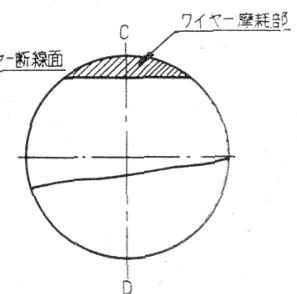

-2 横断面 $(\mathrm{A}-\mathrm{B})$ 第 5 図索道実験に括して発生したワイヤの割れ

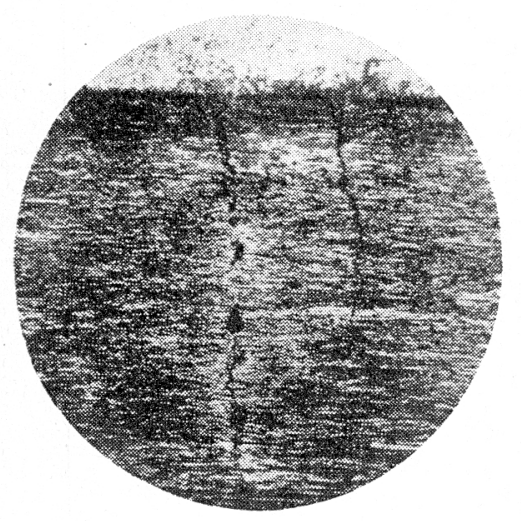

军真 3

$74+$ 紸断面
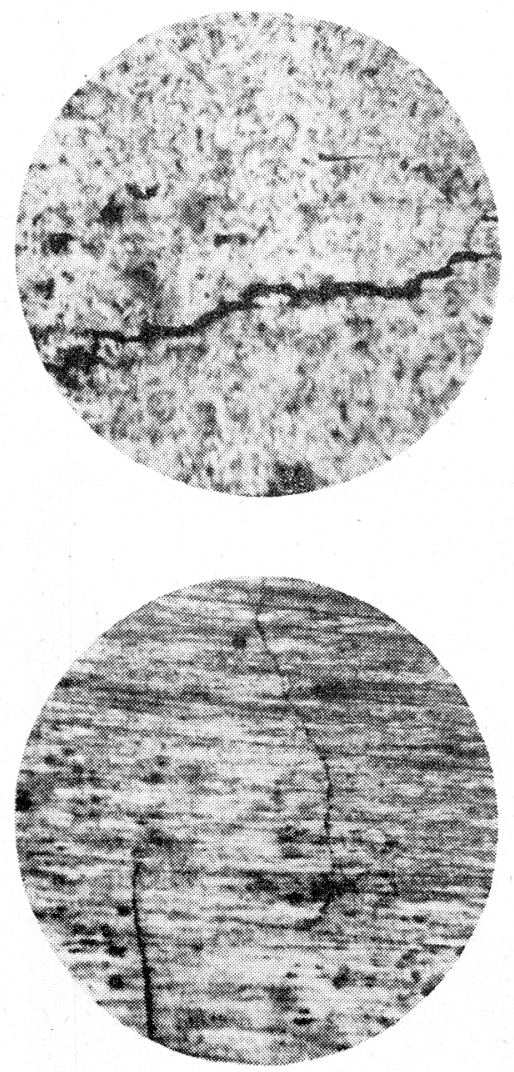

写真 4

\section{ワイヤ}

横断面

(第 5 図 -1

$\mathrm{A}-\mathrm{B}$ 断

画)

写真 5

ワイヤ

維断面

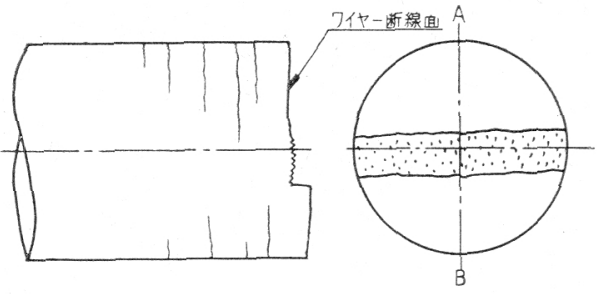

縱断面 $(A-B)$

第6図ワイヤ試験機試料に発生した䑖れ

な試料で法，破断した部分以外に割秃は見当らない。 た前者の上うな滑車を用いた軌萦の亦た断線しない萦の 上面のワイヤを調ベて見ても割机が入つているが，後者 では見当らない。いずれの試料でも割れはワイヤ上面の゙

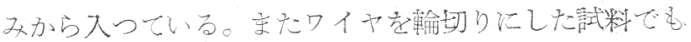
ワイヤ摩耗面と添添平行に割秃の見党るるのも㐫つた。

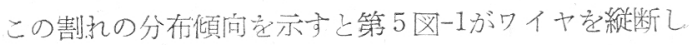
たもので, 第5図一2はワイヤを輪切りにしたものである。 军真 3,4 はいずれも試料断面の顕微鏡写真である。写真 3はワイヤを縦に，写真4 は輸切りにした断面である。

\section{2 素線断線試験}

$4 \cdot 2 \cdot 1$ 割㣗について 素線張力 $150 \mathrm{~kg}$, 上下スト ーク $60 \mathrm{~mm}$ て大体ローシー上下回数が約 8,000 回で等線 は甽断されるが，この切断した破片を試料として調べた 結果について述べる。破断面はローラーに接触した部分

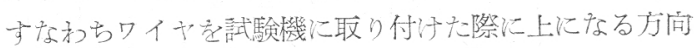
ととの反対側すなっち下の方向は滑らかな白い破断面で

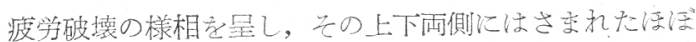
中央部が黑いギザギザの四らの㐫る脆い破面を呈してい た。この試料を 4 ・1.2 て述べたと同様の方法でロイヤを

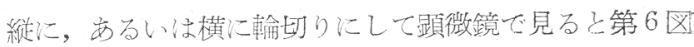

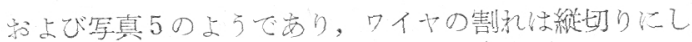
たものではいくぶれ上から大つた割れは長いが，上下両

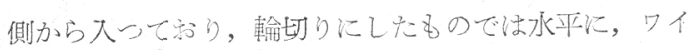
ヤ軸線に平行に割九がスっている。

4.2.2 ワイヤが曲げられる事により発生するワイヤ 下面のヒズミ $3 \cdot 2$ 亿示した装置により, ワイヤを掤 乙付壮るローラの材料老軟鋼, 鋳鉃, 鋳鋼に变化してワ イヤ下面に起るヒズミ老測定したところ第 2 表に示与結 果老得た。同表に泳ローラの硬さもとも江示した。材料

第2表 ワイヤの曲将によつて生ずるワイヤ外側の ヒズミ測定表

\begin{tabular}{|c|c|c|c|}
\hline ローラ村質 & $\begin{array}{c}\text { 只-ラ硬さ } \\
\text { HVN (HRB) }\end{array}$ & 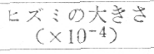 & 滑車番号* \\
\hline $\begin{array}{l}\text { 整鋼 } \\
\text { 普涌鋳鉄 } \\
\text { 銀 鋼 }\end{array}$ & $\begin{array}{r}<150(68) \\
174(82.5) \\
192(88)\end{array}$ & $\begin{array}{l}20.91 \\
21.06 \\
21.13\end{array}$ & $\begin{array}{l}\text { No. } 17 \\
\text { No. } 16 \\
\text { No. } 25\end{array}$ \\
\hline
\end{tabular}

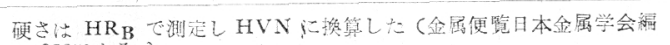
P. 352 上官。)

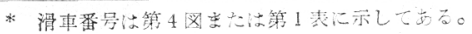


の種類が 3 種類で少ないのであるが，ローラの形が同一 であつてもローラの材質が軟い:どワイヤの曲げによつ て生ずるワイヤ外側の弓張ヒズミは少ないことを示して いる。

\section{5. 考察}

4・2・1 の実験に和いてローラを下向きストロークの最 低位まで動かして後，ワイヤに張力を与えるための重銼 をはずして試験㙨からワイヤを取りはずして見ると, 最 後淁触していた点でワイヤは「く」の字に曲つてい る。このことはここに述べる委でもなくワイヤには弾性 限界以上の店力が加えられたため永久変形を起したの であり，はじあ真直であつたものがローラに押しつけら れたことによってワイヤ上部に圧縮灾力を受け，下部に 甹張応力が働、て永入变形学起し，これがローラがス卜 ロークの最上位にもどることによつてワイヤが真直ぐに なる。このことによつてワイヤ上部には先と反対に引㖘

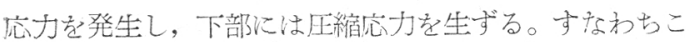
の場合は片振り疲学試験のように見受けられるが, 実際 飞は両振りの交互荷重による波学試験である。交た口イ ヤ上面はローラにより强圧を受け，ローラとの接触点は ローラの下向運動に上り変化するので, ワイヤ上面は下 面上り激しい忘力が折光られるため, ワイヤ上面から割 れの入るのは了解できることである。

\section{6. 結論}

以上の実験結果を⿱亡めて見ると，次のようである。
（1）軦索に生ずる断線は滑車硬さが大きいと早く発 生し，軟かい子小そく発生与方。

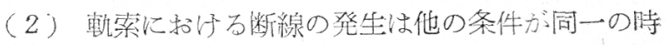
は軌索撓及が大きいと早く発生し，小さいと和そく発生 与る。

(3) 断線は割れがロイヤの上側から発生して切れる 場合と，上と下から割れが発生して切れる場合の二つの 場合がある。

（4）軟かい滑車を用いた場合，ワイヤに発生する嚷 れも少なく, 察た楽線も扣そく発生し, さらに断線数の 增加速度も和只い。

（5）軟か心滑車定使うと硬い滑車を使5場合に比較 してワイヤに与它ヒズミは小さい。

最後に，実験の終始御慜篤な御指導を賜り孪した本学 教授，五十葻博士ならびに政協力を惜し李なかつた東京 製綱株式会社の各位拈よび本実験に熱心に御手伝下さつ た本学石川技官に対し厚く感謝申上げます。

\section{参考 文 献}

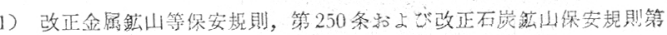
338 条

2) 新保，第 5 回ワイヤロープ满演会講演集 (1956).

3) 新保，2) に同已

4) 吉野: 第 4 回

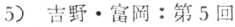

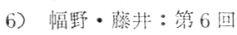

7) 上北・川端：第 5 回

8）新保・熊谷: 筋 4 回

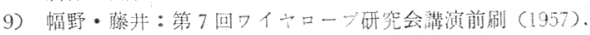

\section{Alacchi 作孔式探炭機}

アレキャンダーシュミット社製の

この切削採炭機は 3 年来フランスの 崖鉱で $55^{\circ}$ の急傾斜切羽に使用され ている。作動の方法はコルフマン社 のBSL 80型と大体同様である。

本採炭機の最適使用範囲㹥層厚 80 〜160cmの間にめる。炭壁を肩進み そし，機栰はその自重約 $3.5 \mathrm{t}$ で游 壁を押しつける。下盤に対しては, 4 本の水力駆動の足で立つて扔り， この足が $35 \mathrm{~cm}$ まで高学老変光るこ とができて下盤の変動を調整する。

作孔式の切削装置および火力駆動 の 2 個の巻胴巻機の原動機々乙て60 kW のモ一夕表装備している。巻胴 巻機の牽引力は3.5〜4 $\mathrm{t}$ てある。一 方の巻機で作栄間採宸機圭釣つて扰
り，他の卷機は採炭機老局に戻す时 に用いる。連行速度は中度のかたさ

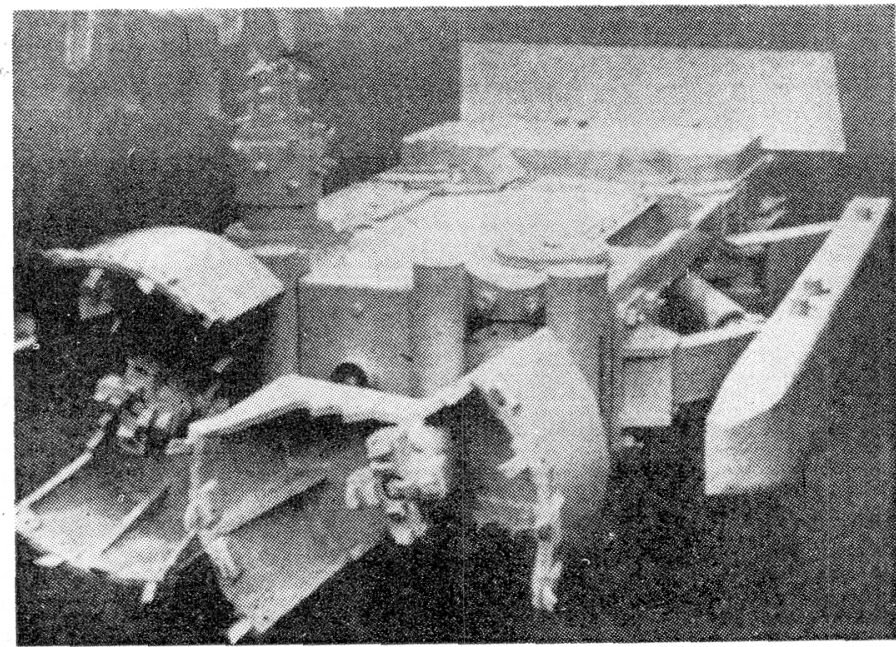

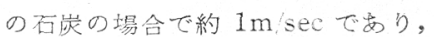
切削の幅は約 $130 \mathrm{~cm}$ である。

(Bergbau Rundschau, Nr. 10, Nov. 1958 より) (山村礼次郎) 